\title{
TMEM204 Gene
}

National Cancer Institute

\section{Source}

National Cancer Institute. TMEM204 Gene. NCI Thesaurus. Code C105105.

This gene is involved in cell-cell adhesion. 